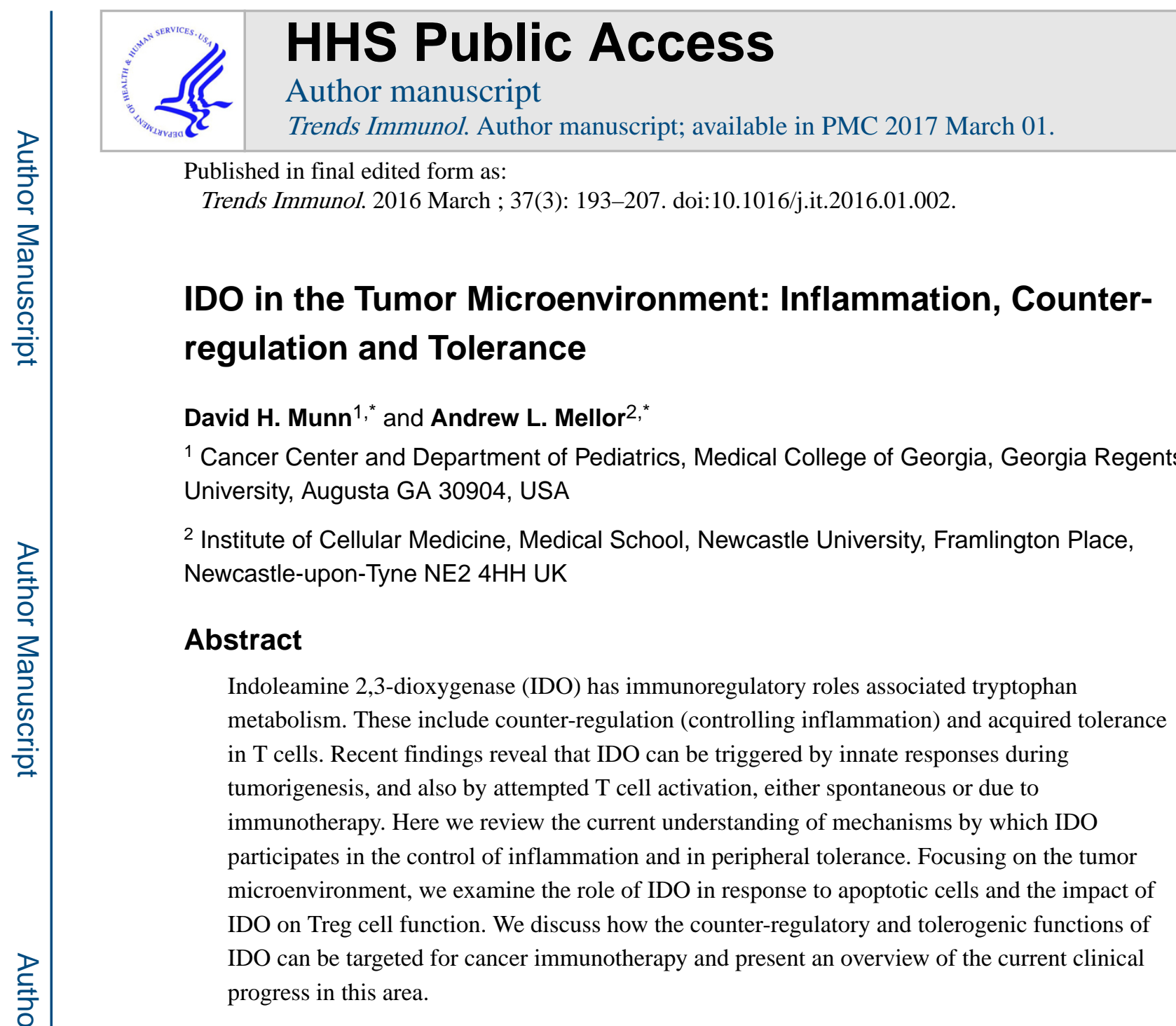

\title{
Introduction
}

The biologic function of the IDO pathway is both counter-regulatory (controlling inflammation) and tolerogenic (creating acquired antigen-specific tolerance in T cells) [1]. Thus, when IDO is genetically deleted or pharmacologically inhibited, mice experience defects in creating tolerance to the fetus during allogeneic pregnancy [1-3], mucosal tolerance $[4,5]$, tolerance to apoptotic cells $[6,7]$ and other forms of acquired peripheral tolerance [8-13]. Conversely, gene-transfer or pharmacologic induction of IDO can create de novo systemic tolerance [6,13-15]. IDO also enhances the tissue-reparative effects of inflammation while limiting the tissue-destructive effects. Thus, blocking or ablating IDO makes inflammation markedly worse in models of graft-versus-host disease [16, 17], autoimmunity [18-21] or chronic infection [22, 23]. In all of these models, however, the role of IDO is focused and selective, and IDO-deficient mice do not have the broad, spontaneous defects in self-tolerance that are seen with mice lacking CTLA-4 or Treg cells. But in

\footnotetext{
*Correspondence: dmunn@gru.edu (D. H. Munn) or andrew.mellor@ncl.ac.uk (A. L. Mellor).

Publisher's Disclaimer: This is a PDF file of an unedited manuscript that has been accepted for publication. As a service to our customers we are providing this early version of the manuscript. The manuscript will undergo copyediting, typesetting, and review of the resulting proof before it is published in its final citable form. Please note that during the production process errors may be discovered which could affect the content, and all legal disclaimers that apply to the journal pertain.
} 
settings where IDO is crucial, it can be an important and non-redundant mechanism of immune regulation.

IDO creates its biologic effects by metabolizing the essential amino acid tryptophan into kynurenine. The IDO family of genes includes IDO1 (the main subject of this review) and IDO2 [24-26]. IDO2 is not redundant with IDO1 but it is much less well studied. In this review, the term "IDO" will refer to IDO1, or to collective functional IDO enzyme activity, unless otherwise specified. Depletion of local tryptophan by IDO can activate the stressresponse kinase GCN2 [27, 28], which senses amino acid withdrawal. GCN2 activation in T cells can inhibit their proliferation, and can bias naive $\mathrm{CD} 4^{+} \mathrm{T}$ cells toward differentiation into Treg cells [27, 29]. In addition, IDO produces soluble factors (kynurenine and downstream metabolites) that bind and activate the aryl hydrocarbon receptor (AhR) [30]. The AhR can promote Treg cell differentiation [29,30], and can also bias dendritic cells (DCs) and macrophages toward an immunosuppressive phenotype [6,31-33]. GCN2 can also directly affect the phenotype of dendritic cells and macrophages [6,33,34]. Together, these pathways can have a profound effect on the APC and the antigen-presenting milieu. Thus, when IDO is active, APCs otherwise capable of producing inflammatory cytokines such as IL-12 instead produce inhibitory cytokines such as IL-10 and TGF $\beta$ [6, 7, 34]. This is a key concept, because it means that IDO up-regulation can alter the nature of the APC itself, and change the whole local milieu from immunogenic to tolerogenic [6, 35].

In 2013 in this journal, we reviewed the role of IDO in creating metabolic signals that regulate immune responses [36]. We discussed the ability of IDO to create local suppression of effector T cells by metabolic depletion of tryptophan and production of tryptophan metabolites; and also to create more widespread systemic tolerance by activating circulating Tregs. We also noted the counter-regulatory role of IDO, which is actively induced by many of the same inflammatory signals that it acts to control. Since that time, IDO has entered multiple Phase II clinical trials in oncology, and has become an increasingly attractive target for cancer immunotherapy. IDO has been shown to play an important role in inducing tolerance to apoptotic cells, which is relevant both for self-tolerance and for the immune response to dying tumor cells. In the current review, we examine how counter-regulatory IDO can be triggered in the tumor microenvironment by innate responses during tumorigenesis, and in established tumors by attempted $\mathrm{T}$ cell activation (either spontaneous or due to immunotherapy). We will describe how IDO may affect signaling pathways in Tregs via PTEN phosphatase, mTOR and PI(3)K. Overall, IDO possesses somewhat different properties from other immune checkpoints in the tumor microenvironment, because it can act upstream to affect the basic choice between tolerogenic or immunogenic crosspresentation of tumor antigens.

\section{IDO and counter-regulation}

The tumor microenvironment is an abnormal milieu, but tumors often recruit and exaggerate the normal regulatory mechanisms that maintain homeostasis and tolerance in the immune system. As we will discuss, many tumors over-express IDO, either in the tumor cells themselves, or in tumor-associated cells such as dendritic cells (DCs), macrophages or endothelial cells. Further complicating this biology, IDO is inducible, and may not be 
expressed until some degree of inflammation occurs in the tumor to drive it [37]. This is a key point, because IDO by its nature tends to be counter-regulatory: i.e., its expression is actively induced by signals from inflammation or $\mathrm{T}$ cell activation, which it then acts to suppress. This inducible counter-regulation is beneficial when IDO is controlling harmful inflammation or creating tolerance to apoptotic cells, but is highly undesirable when it is suppressing the immune system's attempted response against the tumor.

\section{Physiologic IDO induction at sites of inflammation}

Interferon types I (IFNa $\beta$ ) and II (IFN $\gamma$ ) are classic hallmarks of inflammation that stimulate immunity. IFNs activate Janus kinase/signal transducer and activator of transcription (JAK/ STAT) complexes to induce transcription of many IFN-stimulated genes (ISGs). Many ISGs promote immunity, but some ISGs regulate immunity and promote tolerance. IFNs are potent inducers of immune regulatory responses mediated by IDO. Mammalian IDO1 gene promoters possess IFN-stimulated response elements (ISRE) and IFN-activated sites (GAS). In contrast, IDO2 genes are weakly responsive to IFNs. Other factors that induce IDO in some cells include aryl hydrocarbon receptor (AhR) ligands and regulatory cytokines, including IL-10 and TGF $\beta$. Select cell types express IDO at sites of inflammation, even though most cells express IFN type I (IFNAR) and type II (IFN $\gamma R$ ) receptors. Infections, vaccines and tumorigenesis induce IFNs that may co-induce IDO, though IDO enzyme activity may not manifest in these settings due to transcriptional, translational and posttranslational controls. Some epithelial cells, dendritic cells (DC) and macrophages can express IDO, while lymphoid cells rarely express IDO. The transcriptional factor DAP12 regulates IFN-induced IDO transcription while SOCS3 targets IDO protein for proteosomal degradation in some cells $[38,39]$. Metabolic factors that regulate IDO enzyme activity include heme cofactor and substrate supply and redox potential. Cells expressing IFN $\gamma$ inducible nitric oxide synthase (iNOS) produce nitric oxide (NO) that blocks IDO activity. Hence IFN $\gamma$ co-induces iNOS and IDO but metabolic cross-regulation may override IDOmediated. In summary, many inflammatory insults induce IDO but multiple factors restrict IDO expression and regulate IDO activity in physiologic settings. IDO expression in tumors

In some tumors, IDO is constitutively expressed by the tumor cells themselves. This may serve as an immune-escape mechanism (which is the focus of this review), or in some cases may confer some non-immune survival advantage on the tumors [40, 41]. IDO can also be expressed in tumor-associated cells such as DCs or endothelial cells. In most studies, high expression of IDO in the tumor or draining LNs has been an adverse prognostic factor. Tumors in this category include melanoma [42-44], colon cancer [45, 46], brain tumors [47], ovarian cancer [48], acute myelogenous leukemia [49,50], and a number of others [51'53]. In a smaller number of tumor types, IDO expression appears to be induced or "reactive" i.e., associated with increased $\mathrm{T}$ cell infiltration and inflammation [37, 54, 55]. In this situation, up-regulation of IDO may be a proxy for a stronger spontaneous anti-tumor immune response, and thus associated with more favorable prognosis [56, 57]. However, even in these immune-responsive patients, the IDO itself is not beneficial, and the patient might do even better if IDO were blocked (this will need to be evaluated empirically in the course of clinical trials). The signals that upregulate reactive IDO in these tumors are not 
known, but IFN $\gamma$ would be a logical candidate, and there is experimental support for this hypothesis [37].

Growing awareness that beneficial anti-tumor inflammation can induce detrimental counterregulatory IDO has implications for clinical immunotherapy. The goal of most immunotherapy is to activate $\mathrm{T}$ cells within the tumor. If these $\mathrm{T}$ cells themselves induce IDO, this might reduce or inhibit the desired anti-tumor effect. While this concern has not yet been tested in clinical trials, preclinical examples have been demonstrated with IL-12 therapy [58] and adoptive cell therapy using CAR-T cells [59]. Thus, immunotherapy regimens that induce extensive inflammation at the site of the tumor might benefit from combination with an IDO-inhibitor drug.

\section{Immune responses to DNA in the tumor microenvironment}

DNA is sensed to activate immune cells. This response is critical for host control of many infectious pathogens, including bacteria ingested by phagocytes and DNA viruses that replicate in cells. Host survival may depend on rapid induction of innate immunity to limit infection spread and incite adaptive immunity to eliminate infections. Toll-Like Receptor-9 (TLR9) is the archetypal DNA sensor that recognizes un-methylated CpG motifs in prokaryotic (bacterial) DNA and mitochondrial DNA. TLR9 expression is restricted to specialized immune cells, including some DCs, macrophages and B cells. These cell types function as sentinels and antigen presenting cells (APCs) that respond rapidly to infections and provoke host immunity. TLR9 is located in endosomes, where it senses ingested pathogen DNA to induce IFNa $\beta$ expression via MyD88 signaling, a classic hallmark of host innate immunity to microbial infection.

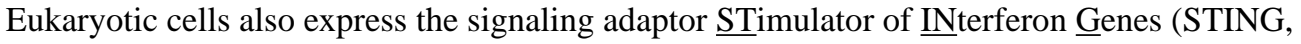
also termed MPYS, Tmem173). STING is downstream of several cytosolic DNA sensors [60], including cyclic GMP-AMP synthase (cGAS). STING interacts with TBK1 and IRF3 signaling proteins and IFN $\beta$ is a prominent target of STING signaling. The mechanism by which DNA sensing activates STING is known for cGAS, which possesses 'zinc thumb' structures that bind to double strand DNA (dsDNA). Once bound to DNA, cGAS undergoes conformational changes that catalyze synthesis of the cyclic dinucleotide (CDN) cGAMP [61]. Cytosolic DNA sensing by cGAS to activate STING/IFN $\beta$ signaling are key steps in rapid responses to infection by many professional APCs and non-APCs.

\section{Cytosolic DNA sensing can incite tumor immunity}

STING/IFNa $\beta$ signaling also incites tumor immunity in mouse models of spontaneous or therapy-induced tumor regression $[62,63]$. Thus B16 melanomas expressing a neo-antigen (SIY) grew faster in STING-deficient mice than STING-sufficient (B6) mice. DNA was sensed via cGAS to activate STING/IFNa $\beta$ signaling and stimulate tumor antigen crosspresentation by CD8 $\mathrm{a}^{+}$DCs that primed T cells. Hence in this immunogenic B16-SIY tumor model, STING/IFNa $\beta$ signaling led to dominant pro-inflammatory responses that impeded tumorigenesis (Figure 1A). These observations identified DNA as a source of proinflammatory signals that incite tumor immunity in the context of immunogenic tumor 
growth. Malignant cells or tumor-associated cells that die are potential sources of DNA that trigger STING/IFNa $\beta$ signaling in the tumor microenvironment. Phagocytes in tumor lesions may ingest dying cells and process DNA and tumor antigens to prime T cells. Strong correlations between IFNa $\beta$ transcriptional signatures and T cell markers in human metastatic melanomas provide clinical significance for the paradigm that DNA sensing in the tumor microenvironment incites $\mathrm{T}$ cell responses [64]. This paradigm also suggests that STING agonists may be exploited to enhance tumor immunity. Indeed, the tumor-disrupting agent DMXAA (Vadimezan) and modified CDNs that activate STING were potent adjuvants for tumor immunotherapy in mice [65]. However, therapeutic responses to Vadimezan were not IFNaß-dependent, hinting that other pathways may incite tumor immunity downstream of STING. Clinical trials revealed no therapeutic benefit of Vadimezan, possibly because human STING is not responsive to the drug due to an amino acid polymorphism [66]. This point notwithstanding, modified CDNs that activate human STING may be effective adjuvants in some cancer patients based on promising therapeutic responses observed in mouse immunogenic tumor models [65].

\section{DNA and STING agonists can promote tolerogenic responses by inducing IDO}

DNA nanoparticles (DNPs) containing cargo DNA and cationic polymers such as polyethylenimine (PEI) are used to transfect genes into cells and live organisms. Unexpectedly, systemic DNP treatments stimulated IDO activity in many mouse tissues due to cargo DNA sensing by innate immune cells [67]. Cargo DNA lacking TLR9 ligands was sensed to induce IDO via a STING/IFNa $\beta$ dependent pathway, though prokaryotic DNA was also sensed via TLR9 to activate NK cells [35]. Cargo DNA was ingested and sensed via STING to stimulate selective IFN $\beta$ expression by myeloid (CD11b) DCs and induce selective IDO up-regulation in DCs expressing the B cell marker CD19. Splenic DCs from DNP-treated mice suppressed T cell responses, activated Tregs and DC ablation abolished IDO-mediated suppression following DNP treatment. Thus discrete DC subsets in lymphoid tissues sense cytosolic DNA to activate STING and mediate IDO-dependent tolerogenic responses.

Consistent with the paradigm that STING can regulate immunity, STING agonists alleviated autoimmune disease syndromes in mice. Systemic DNP treatments alleviated limb joint damage in an antigen-induced arthritis model [67], while DNPs and synthetic CDNs slowed experimental autoimmune encephalitis (EAE), a model of multiple sclerosis, and also alleviated established EAE [68]. In both models, tolerogenic and therapeutic responses to STING agonists were abolished in mice lacking STING, IFNa $\beta$ receptor or IDO1 genes, and in mice given IDO inhibitor. Thus when administered systemically STING agonists are tolerogens due to their ability to induce IDO. 


\section{Cellular DNA in aseptic tissues is sensed to incite or inhibit autoimmunity via STING}

Diametric immune responses to cytosolic DNA during immunogenic tumor growth and after DNP treatment highlight the critical need to understand how cellular DNA is processed and sensed to activate STING in local settings of inflammation. Release of DNA and intracellular autoantigens from dying cells may compromise tolerogenic processes that prevent autoimmunity. Moreover, inflammation lowers tolerance thresholds and increases cell death to enhance the risk of inciting autoimmunity. Unlike live cells that incite immunity, apoptotic cells promote tolerance to alloantigens they express. Systemic administration of apoptotic thymocytes incited robust tolerogenic responses in mice via an IDO-dependent pathway [7]. Thus pre-treating female B6 mice with male apoptotic cells protected male skin allografts from rejection, while male allografts were rejected by females given IDO inhibitors during pre-treatment [6]. Moreover, STING ablation abolished IDO and regulatory cytokine (IL-10, TGF $\beta$ ) induction after apoptotic cell treatment, which instead stimulated pro-inflammatory IL-6 expression [35]. Thus apoptotic cell DNA was sensed via cytosolic DNA sensors to promote tolerance via IDO. Like DNPs that resemble chromatin, DNA complexes from dying cells may be ingested by phagocytes that process DNA to activate STING/IFNa $\beta$ signaling and promote tolerogenic responses via IDO. Marginal zone (MZ) macrophages expressing CD169 mediated tolerogenic responses to apoptotic cells, though other MZ cell subsets may collaborate with CD169+ MZ to coordinate processing of apoptotic cell antigens and DNA to elaborate tolerogenic responses. By analogy, immune cells that infiltrate developing malignancies or reside in draining lymph nodes may be specialized to promote tolerance via IDO in response to cytosolic DNA sensing. Some potential factors likely to influence immune responses to DNA in the tumor microenvironment include: (1) cell death rates and pathways of cell death; (2) physiologic context that may promote distinct inflammatory responses during tumorigenesis and; (3) genetic, environmental and immunologic factors that impact the local balance between tolerance and immunity.

Striking illustrations of the potential for tissue DNA to break tolerance emerged from studies on mice with defects in DNA catabolism. Mice lacking the DNAses Trex-1 or DNAse-II succumbed to spontaneous hyper-inflammatory and autoimmune syndromes, leading to death several months after birth or embryonic death, respectively $[69,70]$. In these models, spontaneous autoimmunity was caused by excessive tissue DNA sensing to activate STING and incite sustained IFN $\beta$ production. Thus in aseptic tissues DNA incited autoimmunity unless DNAse activity degraded excess DNA, suggesting that cell death during tissue homeostasis, growth or re-modeling has the potential to incite STING/IFNa $\beta$ signaling that can overcome local tolerance.

Conversely in some physiologic settings, active tolerogenic responses to tissue DNA may maintain peripheral tolerance when cells die, even when DNAse activity is not compromised. Support for this paradigm emerged from studies on MRL ${ }^{\text {lpr }}$ mice prone to systemic lupus-like autoimmune syndromes since STING-deficient MRL ${ }^{\text {lpr }}$ mice were more susceptible to lupus than their STING-sufficient counterparts. [71] Moreover, macrophages

Trends Immunol. Author manuscript; available in PMC 2017 March 01. 
were hyper-responsive to TLR ligands, while IDO expression and Treg numbers were reduced substantially in STING-deficient MRL ${ }^{\text {lpr }}$ mice. These observations are consistent with findings that IDO inhibitors accelerated lupus progression in MRL ${ }^{\text {lpr }}$ mice and that IDO1 gene ablation conferred lupus susceptibility following chronic exposure to apoptotic cells [7]. Therapeutic responses to STING agonists that alleviated autoimmune diseases also support the paradigm that DNA sensing to activate STING can reinforce tolerogenic processes $[67,68]$. Collectively, studies on mice with defective DNAse function and MRL ${ }^{\text {lpr }}$ mice reveal opposing immunologic responses to cytosolic DNA that incite or suppress autoimmunity, respectively. Thus cytosolic DNA sensing to stimulate STING/IFNa $\beta$ signaling is a pivotal pathway able to drive dominant tolerogenic or immunogenic responses. Multiple factors are likely to impact the direction of immune responses to DNA, STING agonists and dying cells. For example, systemic administration of DNPs, STING agonists and apoptotic cells is essential for dominant tolerogenic responses to manifest in mice.

\section{STING and IDO in the tumor microenvironment}

The paradigm that DNA can drive opposing immunologic outcomes is pertinent to understanding how DNA influences immune responses in the tumor microenvironment. As discussed above, DNA sensing to activate STING/IFNa $\beta$ signaling slowed growth of immunogenic tumors and potentiated tumor regression after therapy [63, 72-74]. Moreover, IFNa $\beta$ signaling impeded growth of carcinogen-induced and transplantable tumors [75]. It is presently unclear how immunogenic responses driven by IFNa $\beta$ can be reconciled with the paradigm that IDO, which is up-regulated by IFNa $\beta$, is often up-regulated during tumorigenesis in mice and cancer patients. Factors that induce and sustain IDO prior to overt tumor formation have not been defined, but may include DNA (by analogy to physiologic IDO induction following DNP or apoptotic cell treatments). Elevated IDO may be an early 'innate' response to local inflammation associated with pre-malignant lesions. IDO may also be induced at later stages of tumorigenesis, when activated myeloid (DCs, M $\varphi s$, MDSCs,) or lymphoid (T, NK) cells infiltrate tumor lesions. IFNs are likely inducers of IDO, though IFNa $\beta$ may be more likely to induce IDO during the early stages of tumorigenesis when cells making IFN $\gamma$ are absent. IDO1-deficient mice were resistant to skin papilloma formation in the DMBA/TPA carcinogenesis model [76] suggesting that IFNs may induce IDO to promote immune escape in this model. Moreover, mice lacking STING genes in bone marrow derived cells were also resistant to papilloma formation after chronic DMBA exposure [77], revealing a critical role for cytosolic DNA sensing by hematopoietic cells in carcinogenesis. These observations suggest that DNA enters cytosolic compartments of hematopoietic cells to promote carcinogenesis, possibly due to STING/IFNa $\beta$ signaling that induces IDO. Infiltrating effector CD8 T cells were also identified as sources of IFN $\gamma$ that induced IDO and create immune checkpoints in the tumor microenvironment of malignant melanomas [37].

Another factor that may influence immune responses to DNA in the developing tumor microenvironment is tumor antigenicity, which is gaining recognition as a key factor determining responsiveness to immunotherapy [78]. As noted above, immunogenic B16-SIY melanomas grew faster in STING-deficient mice. In the same study, parental B16 melanomas grew at comparable rates in STING-deficient and wild-type mice not given 
therapy [65]. Thus DNA sensing to activate STING had no significant impact of tumorigenesis in the absence of tumor neo-antigens, indicating that enhanced tumor antigen recognition was essential for DNA to promote tumor immunity, lower tolerance thresholds and impede tumorigenesis (Fig. 1A)., Tumors with relatively low antigenicity may be less likely to overcome innate tolerizing responses to DNA that suppress tumor immunity and promote tumorigenesis (Fig. 1B). Similar questions arise regarding immune responses to DNA following therapy because DNA sensing may help restore or reinforce tumor tolerance by stimulating IDO. Reports that STING impeded growth of immunogenic tumors and mediated therapeutic effects suggest that immunogenic responses to DNA overcame local tolerogenic processes in these models [62,63]. However this paradigm may not apply to all tumor models, especially tumors with low antigenicity. In such settings tolerance may be more robust, making it more difficult to overcome counter-regulatory responses established during tumorigenesis, including DNA driven IDO up-regulation (Fig. 1B). Similar considerations may also help explain why therapeutic responses to STING agonists (CDNs) were effective in some but not all tumor models [63, 65]. Thus, DNA sensed in the tumor microenvironment creates an innate immune adjuvant effect that can potentiate efforts to stimulate tumor immunity. However, immune responses to DNA during tumorigenesis and in response to immunotherapy can vary - boosting immune recognition and effector responses, or inducing tolerogenic IDO, as it does for DNP cargo DNA and DNA released by apoptotic cells. Thus, it may be necessary to determine empirically whether DNA sensing to activate STING promotes immunity or tolerance in a particular tumor setting. This point notwithstanding, it seems likely from recent developments that STING agonists may be of most benefit in tumors that exhibit relatively high immunogenicity.

\section{IDO and Treg cells}

We now turn from innate inflammation to regulation of adaptive immune responses. One of the major pathways by which IDO can affect $\mathrm{T}$ cell immune responses is via activation of suppressive Treg cells.

\section{Activation of Treg cells by IDO}

Regulatory T cells are a major suppressive mechanism in tumors [79]. IDO controls one important activation pathway for Tregs in the tumor microenvironment. Resting Tregs are not suppressive [80] and must undergo some form of activation in order to become functional. This activation step requires TCR engagement [81], but it is also highly sensitive to modulating signals from the local milieu. These environmental signals can dictate the functional properties of the activated Tregs [82]. When Tregs are activated by an IDOexpressing APC, they acquire properties that are very different from the conventional in vitro systems using anti-CD3 mitogen [83]. One difference is that IDO-induced Treg activation is triggered by physiologic signals from activating effector T cells; this has recently been shown to be a key stimulus for Treg activation in vivo [84]. A second important difference is that the presence of IDO markedly affects the outcome of Treg activation by regulating mTORC 2 and Akt signaling in the Treg, as summarized in Figure 2. 
One of the effects of IDO is to reduce the local tryptophan concentration in the vicinity of the responding Treg. This low tryptophan activates a stress-response pathway in the Tregs mediated by the kinase GCN2 $[27,85]$. Then, via a process that is not yet well understood, GCN2 inhibits the activity of the mTORC2 complex, and prevents it from phosphorylating Akt on its activating Ser473 site [86]. Akt is emerging as an important control-point for Treg activation in tumors [86, 87]. Unlike effector T cells, which need Akt signaling for normal activation, Akt signaling in Tregs inhibits their function [88]. More precisely, Akt destabilizes the Tregs and causes them to lose their suppressive activity [86, 89]. These destabilized Tregs may then reprogram into pro-inflammatory effector cells [90-92], which have been termed "ex-Tregs" [89, 93, 94]. Thus, one of the important functions of IDO during Treg activation is to inhibit Akt and thus prevent destabilization and maintain the suppressive phenotype.

Akt triggers inactivation and degradation of the FOXO transcription factors FoxO1 and FoxO3, which are important for Treg suppressor function [95]. Thus, by inhibiting the mTOR/Akt axis, IDO allows Tregs to up-regulate FoxO3a; and this in turn allows them to up-regulate PD-1 expression [86]. When this PD-1 is engaged by its ligands PD-L1 or PDL2, it activates the PTEN lipid phosphatase, which then inhibits PI3K activity and blocks phosphorylation of Akt on its other activating site, Thr308 (Figure 2). Thus, IDO-activated Tregs establish a PD-1 $\rightarrow$ PTEN signaling loop that stably maintains inhibition of Akt, as long as PD-1 is engaged by its ligands. (And, since IDO-activated Tregs are potent inducers of PD-L1 and PD-L2 expression on DCs [83], it is likely that PD-1 will remain engaged.) This PD1 $\rightarrow$ PTEN feedback loop thus provides a molecular explanation for the earlier observation, seen in multiple models, that IDO-induced Treg activity is strictly dependent on the PD-1/PD-ligand pathway in order to create suppression [67, 83, 96, 97].

Taken together, these data suggest that when Tregs are activated in the presence of IDO, this initiates a stable self-perpetuating suppressive state in the Tregs that becomes independent of IDO, and instead is maintained long-term by the loop between PD-1 signaling and PTEN. This has important implications, because IDO expression is localized and relatively restricted, whereas PD-ligands are widely inducible on antigen-presenting cells, tumor cells and other tissues. Thus, IDO-activated Tregs could potentially create sustained suppression far from the original source of IDO. More speculatively, it is possible that other metabolic stresses that could block the mTOR/Akt pathway during Treg activation (e.g., arginine deprivation due to arginase I expression) might also initiate the same stable, PTEN-driven activation loop. Conversely, activation signals might target PTEN directly. Neuropilin-1 (Nrp1) on Tregs is an important pathway that contributes to immune suppression within the tumor microenvironment [98]. Nrp1 activates PTEN, inhibits Akt, preserves FoxO3a and stabilizes Treg suppressor activity [98]. Thus, Nrp1 might establish the same stable, selfsustaining, PTEN-driven Treg phenotype via direct action on PTEN, and IDO may be just one of several upstream pathways that converge on PTEN during Treg activation. 


\section{IDO and tolerance to apoptotic cells}

\section{Physiologic tolerance to apoptotic self cells}

One important physiologic pathway that may depend strongly on the link between IDO and

PTEN is the tolerogenic response to apoptotic cells. IDO appears to play a significant role in maintaining tolerance to apoptotic cells. When normal mice are challenged with apoptotic thymocytes, they maintain tolerance to self antigens [7], and will create de novo tolerance to new antigens introduced on the apoptotic cells [6]. However, if IDO1 is genetically ablated or pharmacologically inhibited, then mice can no longer maintain tolerance when challenged with apoptotic cells, and rapidly develop lupus-like autoimmunity [6, 7]. Apoptotic cells injected intravenously were taken up by macrophages in the spleen, which triggered upregulation of IDO [7]. IDO then altered the phenotype of both the macrophages and of neighboring cells: promoting expression of tolerogenic IL-10 and TGF $\beta$, inhibiting production of immunogenic IL-12, altering the phenotype of local cross-presenting DCs, and recruiting suppressive Tregs [6, 99]. Thus, IDO affected more than just T cell activation: it modified the properties of the antigen-presenting cells themselves, and altered the whole antigen-presenting milieu. Relevant to tumor immunology, the key point from these studies is that apoptotic cells were not inherently "invisible" or tolerogenic. If they were prevented from inducing IDO, then even self cells became inflammatory and immunogenic.

In the case of apoptotic tumor cells, a similar tolerogenic role for IDO was observed. Subcutaneous injection of apoptotic tumor cells caused activation of IDO, with IDOdependent induction of suppressive PTEN-expressing Tregs [86]. Mice with a genetic deletion of PTEN in Tregs could not create IDO-induced tolerance to the apoptotic tumor cells [86]. (Of note, these PTEN-deficient mice also show the same lupus-prone phenotype as IDO1-KO mice when challenged with apoptotic self cells [86].) Generalization of these findings to the tumor microenvironment in vivo is still speculative, but tumors are constantly faced with the need to inhibit the immune response to dying tumor cells. This becomes particularly acute during the wave of tumor cell death after chemotherapy or radiation. Thus, given the natural physiologic role of IDO in eliciting tolerance to apoptotic cells, it may be that tumors "hijack" this pathway to suppress immune response against dying tumor cells.

\section{IDO and immunogenic tumor cell death}

In principle, tumor cells should be much more immunogenic than normal cells. Tumors have many mutational neoantigens, and even authentic self antigens may be aberrantly expressed in such a way that they become immunogenic [100]. Consistent with this, certain forms of chemotherapy have been shown to elicit a form of immunogenic tumor cell death that triggers inflammation and $\mathrm{T}$ cell responses (reviewed in ref. [101]). Given the widespread use of chemotherapy in the clinic, this is potentially an extremely valuable pathway. However, in practice this phenomenon has been restricted primarily to anthracycline chemotherapy, and to certain transplantable tumor models. But if it could be made more widely applicable, immunogenic cell death could be a powerful tool for therapy. Hence, there is considerable interest in enhancing the immunogenic effects of chemotherapy by combination with immunomodulatory agents [102, 103]. 
The role of IDO and IDO-activated PTEN-Tregs in suppressing the response to apoptotic cells raises the possibility that immunogenic cell death may actually be more widespread - and occur in more settings - than previously recognized. Figure 3 summarizes the possibility that, during tumor cell death, two sets of opposing signals may be created simultaneously. When tumor cells die - whether by chemotherapy, radiation or immunotherapy - some fraction will presumably die by traditional apoptosis. These apoptotic tumor cells will deliver the same tolerogenic signals created by any apoptotic cells (TGF $\beta$, induction of IDO via STING and other pathways, and IDO-induced activation of PTEN-Tregs), as described in refs. [7] and [86]. Simultaneously, however, any tumor cells that die via dysregulated forms of cell death (immunogenic cell death, necrosis or necroptosis) will deliver inflammatory signals. Since tumor cells are so aberrant and disorganized, it seems likely that there may always some component of immunogenic (inflammatory) death combined with the apoptotic cell death. The question then becomes which set of signals - tolerogenic or immunogenic - is dominant. Unless the signal from immunogenic cell death is very strong, IDO and Tregs may predominate - thus masking the fact that many tumor cells are potentially immunogenic. This hypothesis is at present still speculative. If correct, however, it would mean that immunogenic tumor cell death may already be widely available in many contexts (e.g., with standard treatments in the clinic), if the dominant effects of IDO and the downstream PTEN-Treg pathway can be removed.

\section{Interaction between IDO and other pathways in the tumor microenvironment}

\section{IDO and other checkpoints}

Currently, inhibitors of the CTLA-4 and PD-1 pathways are rapidly advancing in the clinic [104]. Results are exciting for certain types of tumors, especially when both pathways are blocked; but most patients with most types of tumors still do not show a response. IDO is linked to both the CTLA-4 and PD-1 checkpoints via complex loops that are not yet fully elucidated. Thus, for example, CTLA-4 expression on Treg cells can up-regulate IDO in DCs [105], while IDO can reciprocally activate Treg cells. IDO also up-regulates PD-1 expression on Treg cells, which contributes to maintenance of PTEN activity [86]. Thus, IDO interacts with other important checkpoints. Mechanistically, however, both CTLA-4 and PD-1 are inhibitory checkpoints that are expressed on T cells; thus, they primarily come into play after antigen has been presented. IDO is somewhat different in that many of its actions occur further upstream, affecting the initial $\mathrm{T}$ cell activation step by altering the biology of the APC itself and the antigen-presenting milieu. Indeed, IDO appears to have certain inherent signaling functions in DCs that are distinct from its tryptophan-catabolizing enzymatic function [106], such that expression of IDO may render the DC more tolerogenic in a cell-intrinsic fashion [107]. Thus, due to its upstream effects on the antigen-presenting milieu, IDO may be non-redundant with the more distal T cell checkpoints, and blocking IDO concurrently with CTLA-4 or PD-1 might confer additive benefit. Preclinical models support this concept, both for CTLA-4 and for PD-1 [108¹10], and clinical trials of these combinations are on-going (see below). 


\section{IDO and MDSCs}

Myeloid-derived suppressor cells (MDSCs) are another important immunosuppressive cell population in the tumor microenvironment. To date, the relationship between IDO and MDSCs has not been well studied. In mouse models, MDSCs suppress T cells via production of reactive oxygen species, nitric oxide or arginase [111], but they do not appear to express IDO. However, IDO may contribute to recruitment of MDSCs into the tumor via more indirect mechanisms [41]; and local IDO and IDO-activated Tregs may increase the suppressor function of MDSCs once they reach the tumor [112]. In humans, several recent reports have described cells with a phenotype consistent with MDSCs, which also express high levels of immunosuppressive IDO [113-115]. Thus, IDO and MDSCs may have more interaction than previously thought, and further study in needed to define the relationship.

\section{IDO and complement}

Finally, the IDO pathway has recently been linked to control of the complement pathway in tumors [116]. The mechanism of this link is still not elucidated, but widespread complement activation was previously described when IDO was blocked during murine pregnancy [3]. In mouse brain tumors, the combination of radiation plus chemotherapy caused extensive complement deposition when IDO was blocked (but not when IDO was active), and this complement was mechanistically required for the effect the of IDO-inhibitor on survival [116]. Further studies are needed to elucidate the mechanism of this link between IDO and complement.

\section{IDO-inhibitors in the clinic}

Mechanistically, IDO-inhibitor drugs do not kill tumor cells directly, nor do they spontaneously initiate an immune response by themselves. Thus, the role for these drugs in the clinic will likely be to allow and enhance the immune responses triggered chemotherapy, vaccine or checkpoint inhibitors. Fortunately, in most studies the toxicity of IDO-inhibitor drugs appears low, even with sustained administration, so combinations should be feasible. Table 1 gives a partial listing of on-going clinical trials of IDO-inhibitor drugs, grouped by combination with chemotherapy or immune-modulator. Two agents currently account for the majority of the trials: indoximod (1-methyl-D-tryptophan), an inhibitor of the IDO pathway [85, 108, 109, 112], and epacadostat (INCB024360) [110, 117, 118]. No final results have yet been published, so it is too early to assess the benefits of these strategies, but anecdotal results have been encouraging. Additional IDO inhibitors are in the development pipeline, as well as agents that may target IDO2 [119] or TDO [120, 121], two other tryptophancatabolizing enzymes that may affect tumor immunity [122].

In monitoring clinical trials of IDO-inhibitors, target-validation studies and pharmacodynamic markers have been somewhat of a challenge. For target detection, there is no accepted set of cross-validated monoclonal antibodies for measuring IDO in clinical biopsy samples. This has made it hard to compare reports from different groups. The issue is further complicated by the fact that IDO is inducible, so the initial (pre-treatment) biopsy may not reflect the status during therapy. Pharmacodynamic markers have also been problematic. Kynurenine, the first metabolic product of IDO, is constitutively present in 
plasma at low levels, because it is produced by TDO in the liver and homeostatic IDO in the gut and elsewhere [123]. In a subset of cancer patients, plasma kynurenine may be elevated by the presence of tumors (ref. [124] and references therein); and in these patients, if kynurenine returns to normal when treated with a with an IDO-inhibitor, then kynurenine is a useful marker of therapy. But in the majority of patients whose kynurenine is already in the normal range to start with, interpretation of kynurenine as a biomarker has been difficult. Target detection and biomarkers are areas that will need additional development as IDOinhibitors enter clinical trials.

\section{Concluding remarks}

The field of cancer immunotherapy has recently entered a more mature phase. It has now become possible to achieve impressive, clinically-meaningful responses in at least a subset of selected patients. Now the question is how to enhance these responses, broaden them, and leverage the power of the patients' own immune system to sustain them. IDO is potentially an attractive target for combinatorial immunotherapy because it affects inflammation, antigen cross-presentation, and the overall tolerogenic milieu. These are areas that are not directly targeted by current existing immunotherapy strategies, so there may be opportunities for synergy. However, more research is needed on a number of open issues (see Outstanding Questions).

The network of immunosuppressive mechanisms in the tumor microenvironment is complex, multifactorial and mutually reinforcing. It is based largely on a pathologic exaggeration of existing, natural regulatory processes in the immune system - especially mechanisms for the counter-regulatory control of inflammation, and for induction of acquired peripheral tolerance. Elucidating the role of IDO in these pathways can help to understand the abnormal biology of the tumor, and identify the most effective way to target IDO for therapy.

\section{References}

1. Munn DH, Zhou M, Attwood JT, Bondarev I, Conway SJ, Marshall B, Mellor AL. Prevention of allogeneic fetal rejection by tryptophan catabolism. Science. 1998; 281:1191-1193. [PubMed: 9712583]

2. Muller AJ, Duhadaway JB, Donover PS, Sutanto-Ward E, Prendergast GC. Inhibition of indoleamine 2,3-dioxygenase, an immunoregulatory target of the cancer suppression gene Bin1, potentiates cancer chemotherapy. Nat. Med. 2005; 11:312-319. [PubMed: 15711557]

3. Mellor AL, Sivakumar J, Chandler P, Smith K, Molina H, Mao D, Munn DH. Prevention of T celldriven complement activation and inflammation by tryptophan catabolism during pregnancy. Nat. Immunol. 2001; 2:64-68. [PubMed: 11135580]

4. Matteoli G, Mazzini E, Iliev ID, Mileti E, Fallarino F, Puccetti P, Rescigno M. Gut CD103+ dendritic cells express indoleamine 2,3-dioxygenase which influences T regulatory/T effector cell balance and oral tolerance induction. Gut. 2010; 59:595-604. [PubMed: 20427394]

5. van der Marel AP, Samsom JN, Greuter M, van Berkel LA, O'Toole T, Kraal G, Mebius RE. Blockade of IDO inhibits nasal tolerance induction. J. Immunol. 2007; 179:894-900. [PubMed: 17617580]

6. Ravishankar B, Liu H, Shinde R, Chaudhary K, Xiao W, Bradley J, McGaha TL. The amino acid sensor GCN2 inhibits inflammatory responses to apoptotic cells promoting tolerance and suppressing systemic autoimmunity. Proc. Natl. Acad. Sci. USA. 2015 
7. Ravishankar B, Liu H, Shinde R, Chandler P, Baban B, Tanaka M, McGaha TL. Tolerance to apoptotic cells is regulated by indoleamine 2,3-dioxygenase. Proc. Natl. Acad. Sci. USA. 2012; 109:3909-3914. [PubMed: 22355111]

8. Sucher R, Fischler K, Oberhuber R, Kronberger I, Margreiter C, Ollinger R, Brandacher G. IDO and regulatory $\mathrm{T}$ cell support are critical for cytotoxic $\mathrm{T}$ lymphocyte-associated Ag-4 Ig-mediated longterm solid organ allograft survival. J. Immunol. 2012; 188:37-46. [PubMed: 22131334]

9. Grohmann U, Orabona C, Fallarino F, Vacca C, Calcinaro F, Falorni A, Puccetti P. CTLA-4-Ig regulates tryptophan catabolism in vivo. Nat. Immunol. 2002; 3:1097-1101. [PubMed: 12368911]

10. Mellor AL, Baban B, Chandler P, Marshall B, Jhaver K, Hansen A, Munn DH. Cutting Edge: Induced indoleamine 2,3 dioxygenase expression in dendritic cell subsets suppresses $\mathrm{T}$ cell clonal expansion. J. Immunol. 2003; 171:1652-1655. [PubMed: 12902462]

11. Guillonneau C, Hill M, Hubert FX, Chiffoleau E, Herve C, Li XL, Anegon I. CD40Ig treatment results in allograft acceptance mediated by CD8CD45RC T cells, IFN-gamma, and indoleamine 2,3-dioxygenase. J. Clin. Invest. 2007; 117:1096-1106. [PubMed: 17404623]

12. Tsai S, Shameli A, Yamanouchi J, Clemente-Casares X, Wang J, Serra P, Santamaria P. Reversal of autoimmunity by boosting memory-like autoregulatory T cells. Immunity. 2010; 32:568-580. [PubMed: 20381385]

13. Lan Z, Ge W, Arp J, Jiang J, Liu W, Gordon D, Wang H. Induction of kidney allograft tolerance by soluble CD83 associated with prevalence of tolerogenic dendritic cells and indoleamine 2,3dioxygenase. Transplant. 2010; 90:1286-1293.

14. Swanson KA, Zheng Y, Heidler KM, Mizobuchi T, Wilkes DS. CDllc+ cells modulate pulmonary immune responses by production of indoleamine 2,3-dioxygenase. Am. J. Respir. Cell Mol. Biol. 2004; 30:311-318. [PubMed: 12959949]

15. Matino D, Gargaro M, Santagostino E, Di Minno MN, Castaman G, Morfini M, Fallarino F. IDO1 suppresses inhibitor development in hemophilia A treated with factor VIII. J. Clin. Invest. 2015; 125:3766-3781. [PubMed: 26426076]

16. Jasperson LK, Bucher C, Panoskaltsis-Mortari A, Taylor PA, Mellor AL, Munn DH, Blazar BR. Indoleamine 2,3-dioxygenase is a critical regulator of acute GVHD lethality. Blood. 2008; 111:3257-3265. [PubMed: 18077788]

17. Lu Y, Giver CR, Sharma A, Li JM, Darlak KA, Owens LM, Waller EK. IFN-gamma and indoleamine 2,3-dioxygenase signaling between donor dendritic cells and $\mathrm{T}$ cells regulates graft versus host and graft versus leukemia activity. Blood. 2012; 119:1075-1085. [PubMed: 22130799]

18. Gurtner GJ, Newberry RD, Schloemann SR, McDonald KG, Stenson WF. Inhibition of indoleamine 2,3-dioxygenase augments trinitrobenzene sulfonic acid colitis in mice. Gastroenterology. 2003; 125:1762-1773. [PubMed: 14724829]

19. Szanto S, Koreny T, Mikecz K, Glant TT, Szekanecz Z, Varga J. Inhibition of indoleamine 2,3dioxygenase-mediated tryptophan catabolism accelerates collagen-induced arthritis in mice. Arthritis Res. Ther. 2007; 9:R50. [PubMed: 17511858]

20. Yan Y, Zhang GX, Gran B, Fallarino F, Yu S, Li H, Xu H. IDO upregulates regulatory T cells via tryptophan catabolite and suppresses encephalitogenic $\mathrm{T}$ cell responses in experimental autoimmune encephalomyelitis. J. Immunol. 2010; 185:5953-5961. [PubMed: 20944000]

21. Fallarino F, Volpi C, Zelante T, Vacca C, Calvitti M, Fioretti MC, Grohmann U. IDO mediates TLR9-driven protection from experimental autoimmune diabetes. J. Immunol. 2009; 183:63036312. [PubMed: 19841163]

22. Romani L, Fallarino F, De Luca A, Montagnoli C, D'Angelo C, Zelante T, Puccetti P. Defective tryptophan catabolism underlies inflammation in mouse chronic granulomatous disease. Nature. 2008; 451:211-215. [PubMed: 18185592]

23. Grohmann U, Volpi C, Fallarino F, Bozza S, Bianchi R, Vacca C, Puccetti P. Reverse signaling through GITR ligand enables dexamethasone to activate IDO in allergy. Nat Med. 2007; 13:579586. [PubMed: 17417651]

24. Metz R, Duhadaway JB, Kamasani U, Laury-Kleintop L, Muller AJ, Prendergast GC. Novel tryptophan catabolic enzyme IDO2 is the preferred biochemical target of the antitumor indoleamine 2,3-dioxygenase inhibitory compound D-1-methyl-tryptophan. Cancer Res. 2007; 67:7082-7087. [PubMed: 17671174] 
25. Ball HJ, Yuasa HJ, Austin CJ, Weiser S, Hunt NH. Indoleamine 2,3-dioxygenase-2; a new enzyme in the kynurenine pathway. Int. J. Biochem. Cel.1 Biol. 2009; 41:467-471.

26. Fatokun AA, Hunt NH, Ball HJ. Indoleamine 2,3-dioxygenase 2 (IDO2) and the kynurenine pathway: characteristics and potential roles in health and disease. Amino Acids. 2013; 45:13191329. [PubMed: 24105077]

27. Munn DH, Sharma MD, Baban B, Harding HP, Zhang Y, Ron D, Mellor AL. GCN2 kinase in T cells mediates proliferative arrest and anergy induction in response to indoleamine 2,3dioxygenase. Immunity. 2005; 22:633-642. [PubMed: 15894280]

28. Rodriguez PC, Quiceno DG, Ochoa AC. L-arginine availability regulates T-lymphocyte cell-cycle progression. Blood. 2007; 109:1568-1573. [PubMed: 17023580]

29. Fallarino F, Grohmann U, You S, McGrath BC, Cavener DR, Vacca C, Puccetti P. The combined effects of tryptophan starvation and tryptophan catabolites down-regulate T cell receptor zetachain and induce a regulatory phenotype in naive T cells. J. Immunol. 2006; 176:6752-6761. [PubMed: 16709834]

30. Mezrich JD, Fechner JH, Zhang X, Johnson BP, Burlingham WJ, Bradfield CA. An interaction between kynurenine and the aryl hydrocarbon receptor can generate regulatory T cells. J. Immunol. 2010; 185:3190-3198. [PubMed: 20720200]

31. Quintana FJ, Murugaiyan G, Farez MF, Mitsdoerffer M, Tukpah AM, Burns EJ, Weiner HL. An endogenous aryl hydrocarbon receptor ligand acts on dendritic cells and T cells to suppress experimental autoimmune encephalomyelitis. Proc. Natl. Acad. Sci. USA. 2010; 107:2076820773. [PubMed: 21068375]

32. Jaronen M, Quintana FJ. Immunological Relevance of the Coevolution of IDO1 and AHR. Front. Immunol. 2014; 5:521. [PubMed: 25368620]

33. Manlapat AK, Kahler DJ, Chandler PR, Munn DH, Mellor AL. Cell-autonomous control of interferon type I expression by indoleamine 2,3-dioxygenase in regulatory CD19(+) dendritic cells. Eur. J. Immunol. 2007; 37:1064-1071. [PubMed: 17343295]

34. Liu H, Huang L, Bradley J, Liu K, Bardhan K, Ron D, McGaha TL. GCN2-dependent metabolic stress is essential for endotoxemic cytokine induction and pathology. Mol. Cell. Biol. 2014; 34:428-438. [PubMed: 24248597]

35. Huang L, Li L, Lemos H, Chandler PR, Pacholczyk G, Baban B, Mellor AL. Cutting edge: DNA sensing via the STING adaptor in myeloid dendritic cells induces potent tolerogenic responses. J. Immunol. 2013; 191:3509-3513. [PubMed: 23986532]

36. Munn DH, Mellor AL. Indoleamine 2,3 dioxygenase and metabolic control of immune responses. Trends Immunol. 2013; 34:137-143. [PubMed: 23103127]

37. Spranger S, Spaapen RM, Zha Y, Williams J, Meng Y, Ha TT, Gajewski TF. Up-regulation of PDL1, IDO, and Tregs in the melanoma tumor microenvironment is driven by CD8+ T cells. Sci. Transl. Med. 2013; 5:200ra116.

38. Orabona C, Pallotta MT, Volpi C, Fallarino F, Vacca C, Bianchi R, Puccetti P. SOCS3 drives proteasomal degradation of indoleamine 2,3-dioxygenase (IDO) and antagonizes IDO-dependent tolerogenesis. Proc. Natl. Acad. Sci. USA. 2008; 105:20828-20833. [PubMed: 19088199]

39. Orabona C, Puccetti P, Vacca C, Bicciato S, Luchini A, Fallarino F, Grohmann U. Toward the identification of a tolerogenic signature in IDO-competent dendritic cells. Blood. 2006; 107:28462854. [PubMed: 16339401]

40. Vareki SM, Rytelewski M, Figueredo R, Chen D, Ferguson PJ, Vincent M, Koropatnick J. Indoleamine 2,3-dioxygenase mediates immune-independent human tumor cell resistance to olaparib, gamma radiation, and cisplatin. Oncotarget. 2014; 5:2778-2791. [PubMed: 24784564]

41. Smith C, Chang MY, Parker KH, Beury DW, DuHadaway JB, Flick HE, Muller AJ. IDO is a nodal pathogenic driver of lung cancer and metastasis development. Cancer discovery. 2012; 2:722-735. [PubMed: 22822050]

42. Munn DH, Sharma MD, Hou D, Baban B, Lee JR, Antonia SJ, Mellor A. Expression of indoleamine 2,3-dioxygenase by plasmacytoid dendritic cells in tumor-draining lymph nodes. J. Clin. Invest. 2004; 114:280-290. [PubMed: 15254595] 
43. Gerlini G, Di Gennaro P, Mariotti G, Urso C, Chiarugi A, Pimpinelli N, Borgognoni L. Indoleamine 2,3-dioxygenase+ cells correspond to the BDCA2+ plasmacytoid dendritic cells in human melanoma sentinel nodes. J. Invest. Dermatol. 2010; 130:898-901. [PubMed: 19829303]

44. Speeckaert R, Vermaelen K, van Geel N, Autier P, Lambert J, Haspeslagh M, Brochez L. Indoleamine 2,3-dioxygenase, a new prognostic marker in sentinel lymph nodes of melanoma patients. Eur J Cancer. 2012; 48:2004-2011. [PubMed: 22033321]

45. Ferdinande L, Decaestecker C, Verset L, Mathieu A, Moles Lopez X, Negulescu AM, Demetter P. Clinicopathological significance of indoleamine 2,3-dioxygenase 1 expression in colorectal cancer. Br. J. Cancer. 2012; 106:141-147. [PubMed: 22108515]

46. Brandacher G, Perathoner A, Ladurner R, Schneeberger S, Obrist P, Winkler C, Amberger A. Prognostic value of indoleamine 2,3-dioxygenase expression in colorectal cancer: effect on tumorinfiltrating T cells. Clin. Cancer Res. 2006; 12:1144-1151. [PubMed: 16489067]

47. Zhai L, Lauing KL, Chang AL, Dey M, Qian J, Cheng Y, Wainwright DA. The role of IDO in brain tumor immunotherapy. J Neurooncol. 2015; 123:395-403. [PubMed: 25519303]

48. Okamoto A, Nikaido T, Ochiai K, Takakura S, Saito M, Aoki Y, Urashima M. Indoleamine 2,3dioxygenase serves as a marker of poor prognosis in gene expression profiles of serous ovarian cancer cells. Clin. Cancer Res. 2005; 11:6030-6039. [PubMed: 16115948]

49. Chamuleau ME, van de Loosdrecht AA, Hess CJ, Janssen JJ, Zevenbergen A, Delwel R, Ossenkoppele GJ. High INDO (indoleamine 2,3-dioxygenase) mRNA level in blasts of acute myeloid leukemic patients predicts poor clinical outcome. Haematologica. 2008; 93:1894-1898. [PubMed: 19050070]

50. Folgiero V, Goffredo BM, Filippini P, Masetti R, Bonanno G, Caruso R, Rutella S. Indoleamine 2,3-dioxygenase 1 (IDO1) activity in leukemia blasts correlates with poor outcome in childhood acute myeloid leukemia. Oncotarget. 2014; 5:2052-2064. [PubMed: 24903009]

51. Balachandran VP, Cavnar MJ, Zeng S, Bamboat ZM, Ocuin LM, Obaid H, DeMatteo RP. Imatinib potentiates antitumor $\mathrm{T}$ cell responses in gastrointestinal stromal tumor through the inhibition of Ido. Nat. Med. 2011; 17:1094-1100. [PubMed: 21873989]

52. Urakawa H, Nishida Y, Nakashima H, Shimoyama Y, Nakamura S, Ishiguro N. Prognostic value of indoleamine 2,3-dioxygenase expression in high grade osteosarcoma. Clin Exp Metastasis. 2009; 26:1005-1012. [PubMed: 19802733]

53. Litzenburger UM, Opitz CA, Sahm F, Rauschenbach KJ, Trump S, Winter M, Platten M. Constitutive IDO expression in human cancer is sustained by an autocrine signaling loop involving IL-6, STAT3 and the AHR. Oncotarget. 2014; 5:1038-1051. [PubMed: 24657910]

54. Denkert C, von Minckwitz G, Brase JC, Sinn BV, Gade S, Kronenwett R, Loibl S. Tumorinfiltrating lymphocytes and response to neoadjuvant chemotherapy with or without carboplatin in human epidermal growth factor receptor 2-positive and triple-negative primary breast cancers. J. Clin. Oncol. 2015; 33:983-991. [PubMed: 25534375]

55. Burstein MD, Tsimelzon A, Poage GM, Covington KR, Contreras A, Fuqua S, Brown PH. Comprehensive Genomic Analysis Identifies Novel Subtypes and Targets of Triple-negative Breast Cancer. Clin. Cancer Res. 2014

56. Jacquemier J, Bertucci F, Finetti P, Esterni B, Charafe-Jauffret E, Thibult ML, Xerri L. High expression of indoleamine 2,3-dioxygenase in the tumour is associated with medullary features and favourable outcome in basal-like breast carcinoma. International journal of cancer. Journal international du cancer. 2012; 130:96-104. [PubMed: 21328335]

57. Riesenberg R, Weiler C, Spring O, Eder M, Buchner A, Popp T, Zimmermann W. Expression of indoleamine 2,3-dioxygenase in tumor endothelial cells correlates with long-term survival of patients with renal cell carcinoma. Clin. Cancer Res. 2007; 13:6993-7002. [PubMed: 18056175]

58. Gu T, Rowswell-Turner RB, Kilinc MO, Egilmez NK. Central role of IFNgamma-indoleamine 2,3dioxygenase axis in regulation of interleukin-12-mediated antitumor immunity. Cancer Res. 2010; 70:129-138. [PubMed: 20028855]

59. Ninomiya S, Narala N, Huye L, Yagyu S, Savoldo B, Dotti G, Ramos CA. Tumor indoleamine 2,3dioxygenase (IDO) inhibits CD19-CAR T cells and is downregulated by lymphodepleting drugs. Blood. 2015; 125:3905-3916. [PubMed: 25940712] 
60. Unterholzner L. The interferon response to intracellular DNA: why so many receptors? Immunobiol. 2013; 218:1312-1321.

61. Civril F, Deimling T, de Oliveira Mann CC, Ablasser A, Moldt M, Witte G, Hopfner KP. Structural mechanism of cytosolic DNA sensing by cGAS. Nature. 2013; 498:332-337. [PubMed: 23722159]

62. Woo S-R, Fuertes Mercedes B. Corrales L, Spranger S, Furdyna Michael J. Leung Michael Y.K. Gajewski Thomas F. STING-dependent cytosolic DNA sensing mediates innate immune recognition of immunogenic tumors. Immunity. 2014; 41:830-842. [PubMed: 25517615]

63. Deng L, Liang H, Xu M, Yang X, Burnette B, Arina A, Weichselbaum RR. STING-Dependent Cytosolic DNA Sensing Promotes Radiation-Induced Type I Interferon-Dependent Antitumor Immunity in Immunogenic Tumors. Immunity. 2014; 41:843-852. [PubMed: 25517616]

64. Fuertes MB, Woo SR, Burnett B, Fu YX, Gajewski TF. Type I interferon response and innate immune sensing of cancer. Trends Immunol. 2013; 34:67-73. [PubMed: 23122052]

65. Corrales L, Glickman LH, McWhirter SM, Kanne DB, Sivick KE, Katibah GE, Gajewski TF. Direct Activation of STING in the Tumor Microenvironment Leads to Potent and Systemic Tumor Regression and Immunity. Cell reports. 2015; 11:1018-1030. [PubMed: 25959818]

66. Conlon J, Burdette DL, Sharma S, Bhat N, Thompson M, Jiang Z, Fitzgerald KA. Mouse, but not human STING, binds and signals in response to the vascular disrupting agent 5,6dimethylxanthenone-4-acetic acid. J. Immunol. 2013; 190:5216-5225. [PubMed: 23585680]

67. Huang L, Lemos HP, Li L, Li M, Chandler PR, Baban B, Mellor AL. Engineering DNA Nanoparticles as Immunomodulatory Reagents that Activate Regulatory T Cells. J. Immunol. 2012; 188:4913-4920. [PubMed: 22516958]

68. Lemos H, Huang L, Chandler PR, Mohamed E, Souza GR, Li L, Mellor AL. Activation of the STING Adaptor Attenuates Experimental Autoimmune Encephalitis. J. Immunol. 2014; 192:5571-5578. [PubMed: 24799564]

69. Ahn J, Gutman D, Saijo S, Barber GN. STING manifests self DNA-dependent inflammatory disease. Proc. Natl. Acad. Sci. USA. 2012; 109:19386-19391. [PubMed: 23132945]

70. Gall A, Treuting P, Elkon KB, Loo YM, Gale M Jr. Barber GN, Stetson DB. Autoimmunity initiates in nonhematopoietic cells and progresses via lymphocytes in an interferon-dependent autoimmune disease. Immunity. 2012; 36:120-131. [PubMed: 22284419]

71. Sharma S, Campbell AM, Chan J, Schattgen SA, Orlowski GM, Nayar R, Fitzgerald KA. Suppression of systemic autoimmunity by the innate immune adaptor STING. Proc. Natl. Acad. Sci. USA. 2015; 112:E710-717. [PubMed: 25646421]

72. Fuertes MB, Kacha AK, Kline J, Woo SR, Kranz DM, Murphy KM, Gajewski TF. Host type I IFN signals are required for antitumor CD8+ T cell responses through CD8 $\{$ alpha $\}+$ dendritic cells. J. Exp. Med. 2011; 208:2005-2016. [PubMed: 21930765]

73. Diamond MS, Kinder M, Matsushita H, Mashayekhi M, Dunn GP, Archambault JM, Schreiber RD. Type I interferon is selectively required by dendritic cells for immune rejection of tumors. J. Exp. Med. 2011; 208:1989-2003. [PubMed: 21930769]

74. Woo SR, Corrales L, Gajewski TF. The STING pathway and the T cell-inflamed tumor microenvironment. Trends Immunol. 2015; 36:250-256. [PubMed: 25758021]

75. Dunn GP, Bruce AT, Sheehan KC, Shankaran V, Uppaluri R, Bui JD, Schreiber RD. A critical function for type I interferons in cancer immunoediting. Nat. Immunol. 2005; 6:722-729. [PubMed: 15951814]

76. Muller AJ, Sharma MD, Chandler PR, DuHadaway JB, Everhart ME, Johnson BAI, Mellor AL. Chronic inflammation that facilitates tumor progression creates local immune suppression by inducing indoleamine 2,3 dioxygenase. Proc. Natl. Acad. Sci. USA. 2008; 105:17073-17078. [PubMed: 18952840]

77. Ahn J, Xia T, Konno H, Konno K, Ruiz P, Barber GN. Inflammation-driven carcinogenesis is mediated through STING. Nat. Commun. 2014; 5:5166. [PubMed: 25300616]

78. Schumacher TN, Schreiber RD. Neoantigens in cancer immunotherapy. Science. 2015; 348:69-74. [PubMed: 25838375]

79. Nishikawa H, Sakaguchi S. Regulatory T cells in cancer immunotherapy. Curr. Opin. Immunol. 2014; 27:1-7. [PubMed: 24413387] 
80. Thornton AM, Piccirillo CA, Shevach EM. Activation requirements for the induction of CD4+CD25+ T cell suppressor function. Eur. J. Immunol. 2004; 34:366-376. [PubMed: 14768041]

81. Levine AG, Arvey A, Jin W, Rudensky AY. Continuous requirement for the TCR in regulatory T cell function. Nat. Immunol. 2014; 15:1070-1078. [PubMed: 25263123]

82. Chaudhry A, Rudensky AY. Control of inflammation by integration of environmental cues by regulatory T cells. J. Clin. Invest. 2013; 123:939-944. [PubMed: 23454755]

83. Sharma MD, Baban B, Chandler P, Hou DY, Singh N, Yagita H, Munn DH. Plasmacytoid dendritic cells from mouse tumor-draining lymph nodes directly activate mature Tregs via indoleamine 2,3dioxygenase. J. Clin. Invest. 2007; 117:2570-2582. [PubMed: 17710230]

84. Liu Z, Gerner MY, Van Panhuys N, Levine AG, Rudensky AY, Germain RN. Immune homeostasis enforced by co-localized effector and regulatory T cells. Nature. 2015 advance online publication.

85. Hou DY, Muller AJ, Sharma MD, Duhadaway JB, Banerjee T, Johnson M, Munn DH. Inhibition of IDO in dendritic cells by stereoisomers of 1-methyltryptophan correlates with anti-tumor responses. Cancer Res. 2007; 67:792-801. [PubMed: 17234791]

86. Sharma MD, Shinde R, McGaha T, Huang L, Holmgaard RB, Wolchok JD, Munn DH. The PTEN pathway in Tregs is a critical driver of the suppressive tumor microenvironment. Science Advances. 2015; 1:e1500845. [PubMed: 26601142]

87. Ali K, Soond DR, Pineiro R, Hagemann T, Pearce W, Lim EL, Vanhaesebroeck B. Inactivation of $\mathrm{PI}(3) \mathrm{K}$ p110delta breaks regulatory T-cell-mediated immune tolerance to cancer. Nature. 2014; 510:407-411. [PubMed: 24919154]

88. Crellin NK, Garcia RV, Levings MK. Altered activation of AKT is required for the suppressive function of human CD4+CD25+ T regulatory cells. Blood. 2007; 109:2014-2022. [PubMed: 17062729]

89. Huynh A, DuPage M, Priyadharshini B, Sage PT, Quiros J, Borges CM, Turka LA. Control of PI(3) kinase in Treg cells maintains homeostasis and lineage stability. Nat. Immunol. 2015; 16:188-196. [PubMed: 25559257]

90. Sharma MD, Huang L, Choi JH, Lee EJ, Wilson JM, Lemos H, Munn DH. An inherently bifunctional subset of Foxp3 T helper cells is controlled by the transcription factor Eos. Immunity. 2013; 38:998-1012. [PubMed: 23684987]

91. Sharma MD, Hou DY, Baban B, Koni PA, He Y, Chandler PR, Munn DH. Reprogrammed Foxp3(+) regulatory T cells provide essential help to support cross-presentation and CD8(+) T cell priming in naive mice. Immunity. 2010; 33:942-954. [PubMed: 21145762]

92. Sharma MD, Hou DY, Liu Y, Koni PA, Metz R, Chandler P, Munn DH. Indoleamine 2,3dioxygenase controls conversion of Foxp3+ Tregs to TH17-like cells in tumor-draining lymph nodes. Blood. 2009; 113:6102-6111. [PubMed: 19366986]

93. Zhou X, Bailey-Bucktrout SL, Jeker LT, Penaranda C, Martinez-Llordella M, Ashby M, Bluestone JA. Instability of the transcription factor Foxp3 leads to the generation of pathogenic memory $\mathrm{T}$ cells in vivo. Nat. Immunol. 2009; 10:1000-1007. [PubMed: 19633673]

94. Bailey-Bucktrout SL, Martinez-Llordella M, Zhou X, Anthony B, Rosenthal W, Luche H, Bluestone JA. Self-antigen-driven activation induces instability of regulatory T cells during an inflammatory autoimmune response. Immunity. 2013; 39:949-962. [PubMed: 24238343]

95. Kerdiles YM, Stone EL, Beisner DL, McGargill MA, Ch'en IL, Stockmann C, Hedrick SM. Foxo transcription factors control regulatory T cell development and function. Immunity. 2010; 33:890904. [PubMed: 21167754]

96. Baban B, Chandler PR, Johnson BA 3rd, Huang L, Li M, Sharpe ML, Mellor AL. Physiologic control of IDO competence in splenic dendritic cells. J. Immunol. 2011; 187:2329-2335. [PubMed: 21813777]

97. Baban B, Chandler PR, Sharma MD, Pihkala J, Koni PA, Munn DH, Mellor AL. IDO activates regulatory T cells and blocks their conversion into Th17-like T cells. J. Immunol. 2009; 183:24752483. [PubMed: 19635913]

98. Delgoffe GM, Woo SR, Turnis ME, Gravano DM, Guy C, Overacre AE, Vignali DA. Stability and function of regulatory $\mathrm{T}$ cells is maintained by a neuropilin-1-semaphorin-4a axis. Nature. 2013; 501:252-256. [PubMed: 23913274] 
99. Ravishankar B, Shinde R, Liu H, Chaudhary K, Bradley J, Lemos HP, McGaha TL. Marginal zone CD169+ macrophages coordinate apoptotic cell-driven cellular recruitment and tolerance. Proc. Natl. Acad. Sci. USA. 2014

100. Coulie PG, Van den Eynde BJ, van der Bruggen P, Boon T. Tumour antigens recognized by T lymphocytes: at the core of cancer immunotherapy. Nat. Rev. Cancer. 2014; 14:135-146. [PubMed: 24457417]

101. Kroemer G, Galluzzi L, Kepp O, Zitvogel L. Immunogenic cell death in cancer therapy. Ann. Rev. Immunol. 2013; 31:51-72. [PubMed: 23157435]

102. Bezu L, Gomes-de-Silva LC, Dewitte H, Breckpot K, Fucikova J, Spisek R, Kroemer G. Combinatorial strategies for the induction of immunogenic cell death. Front. Immunol. 2015; 6:187. [PubMed: 25964783]

103. Belvin M, Mellman I. Is all cancer therapy immunotherapy? Sci. Transl. Med. 2015; 7:315fs348$315 \mathrm{fs} 348$.

104. Lesokhin AM, Callahan MK, Postow MA, Wolchok JD. On being less tolerant: enhanced cancer immunosurveillance enabled by targeting checkpoints and agonists of T cell activation. Sci. Transl. Med. 2015; 7:280sr281.

105. Fallarino F, Grohmann U, Hwang KW, Orabona C, Vacca C, Bianchi R, Puccetti P. Modulation of tryptophan catabolism by regulatory T cells. Nat. Immunol. 2003; 4:1206-1212. [PubMed: 14578884]

106. Pallotta MT, Orabona C, Volpi C, Vacca C, Belladonna ML, Bianchi R, Grohmann U. Indoleamine 2,3-dioxygenase is a signaling protein in long-term tolerance by dendritic cells. Nat. Immunol. 2011; 12:870-878. [PubMed: 21804557]

107. Pallotta MT, Orabona C, Bianchi R, Vacca C, Fallarino F, Belladonna ML, Grohmann U. Forced IDO1 expression in dendritic cells restores immunoregulatory signalling in autoimmune diabetes. Journal of cellular and molecular medicine. 2014; 18:2082-2091. [PubMed: 25215657]

108. Holmgaard RB, Zamarin D, Munn DH, Wolchok JD, Allison JP. Indoleamine 2,3-dioxygenase is a critical resistance mechanism in antitumor T cell immunotherapy targeting CTLA-4. J. Exp. Med. 2013; 210:1389-1402. [PubMed: 23752227]

109. Wainwright DA, Chang AL, Dey M, Balyasnikova IV, Kim CK, Tobias A, Lesniak MS. Durable therapeutic efficacy utilizing combinatorial blockade against IDO, CTLA-4, and PD-L1 in mice with brain tumors. Clin. Cancer Res. 2014; 20:5290-5301. [PubMed: 24691018]

110. Spranger S, Koblish HK, Horton B, Scherle PA, Newton R, Gajewski TF. Mechanism of tumor rejection with doublets of CTLA-4, PD-1/PD-L1, or IDO blockade involves restored IL-2 production and proliferation of CD8(+) T cells directly within the tumor microenvironment. J. Immunother. Cancer (JITC). 2014; 2:3. [PubMed: 24829760]

111. Ugel S, De Sanctis F, Mandruzzato S, Bronte V. Tumor-induced myeloid deviation: when myeloid-derived suppressor cells meet tumor-associated macrophages. J. Clin. Invest. 2015; 125:3365-3376. [PubMed: 26325033]

112. Holmgaard RB, Zamarin D, Li Y, Gasmi B, Munn DH, Allison JP, Wolchok JD. Tumor-expressed IDO recruits and activates MDSCs in a Treg-dependent manner. Cell reports. 2015; 13:412-424. [PubMed: 26411680]

113. Yu J, Du W, Yan F, Wang Y, Li H, Cao S, Ren X. Myeloid-derived suppressor cells suppress antitumor immune responses through IDO expression and correlate with lymph node metastasis in patients with breast cancer. J. Immunol. 2013; 190:3783-3797. [PubMed: 23440412]

114. Jitschin R, Braun M, Buttner M, Dettmer-Wilde K, Bricks J, Berger J, Mougiakakos D. CLL-cells induce IDOhi CD14+HLA-DRlo myeloid-derived suppressor cells that inhibit T-cell responses and promote TRegs. Blood. 2014; 124:750-760. [PubMed: 24850760]

115. Zhang H, Maric I, DiPrima M, Khan J, Orentas R, Kaplan R, Mackall C. Fibrocytes represent a novel MDSC subset circulating in patients with metastatic cancer. Blood. 2013; 122:1105-1113. [PubMed: 23757729]

116. Li M, Bolduc AR, Hoda MN, Gamble DN, Dolisca SB, Bolduc AK, Johnson TS. The indoleamine 2,3-dioxygenase pathway controls complement-dependent enhancement of chemoradiation therapy against murine glioblastoma. J. Immunother. Cancer (JITC). 2014; 2:21. [PubMed: 25054064] 
117. Liu X, Shin N, Koblish HK, Yang G, Wang Q, Wang K, Scherle PA. Selective inhibition of indoleamine 2,3-dioxygenase (IDO1) effectively regulates mediators of anti-tumor immunity. Blood. 2010; 115:3520-3530. [PubMed: 20197554]

118. Koblish HK, Hansbury MJ, Bowman KJ, Yang G, Neilan CL, Haley PJ, Fridman JS. Hydroxyamidine inhibitors of indoleamine-2,3-dioxygenase potently suppress systemic tryptophan catabolism and the growth of IDO-expressing tumors. Molecular cancer therapeutics. 2010; 9:489-498. [PubMed: 20124451]

119. Bakmiwewa SM, Fatokun AA, Tran A, Payne RJ, Hunt NH, Ball HJ. Identification of selective inhibitors of indoleamine 2,3-dioxygenase 2. Bioorg Med Chem Lett. 2012; 22:7641-7646. [PubMed: 23122865]

120. Opitz CA, Litzenburger UM, Sahm F, Ott M, Tritschler I, Trump S, Platten M. An endogenous tumour-promoting ligand of the human aryl hydrocarbon receptor. Nature. 2011; 478:197-203. [PubMed: 21976023]

121. Pilotte L, Larrieu P, Stroobant V, Colau D, Dolusic E, Frederick R, Van den Eynde BJ. Reversal of tumoral immune resistance by inhibition of tryptophan 2,3-dioxygenase. Proc. Natl. Acad. Sci. USA. 2012; 109:2497-2502. [PubMed: 22308364]

122. Ball HJ, Jusof FF, Bakmiwewa SM, Hunt NH, Yuasa HJ. Tryptophan-catabolizing enzymes party of three. Front. Immunol. 2014; 5:485. [PubMed: 25346733]

123. Yoshida R, Urade Y, Nakata K, Watanabe Y, Hayashi O. Specific induction of indoleamine 2,3dioxygenase by bacterial lipopolysaccharide in the mouse lung. Arch. Biochem. Biophys. 1981; 212:629-637. [PubMed: 6976775]

124. Creelan BC, Antonia S, Bepler G, Garrett TJ, Simon GR, Soliman HH. Indoleamine 2,3dioxygenase activity and clinical outcome following induction chemotherapy and concurrent chemoradiation in Stage III non-small cell lung cancer. Oncoimmunology. 2013; 2:e23428. [PubMed: 23802083] 


\section{Trends Box}

- IDO can be induced in the tumor microenvironment by the spontaneous inflammation and $\mathrm{T}$ cell activation associated with many tumors; however, IDO may also be induced reactively, in response to inflammation induced by anti-tumor immunotherapy.

- $\quad$ IDO is rapidly induced when mice are challenged with apoptotic cells. Inhibiting or genetically deleting IDO results in loss of self-tolerance to apoptotic cell-associated antigens, and susceptibility to lupus-like autoimmunity.

- DNA-containing nanoparticles can induce immunosuppressive IDO via a pathway dependent on the STING sensor of cytosolic DNA

- When Tregs cells are activated in the presence of IDO, they up-regulate a highly suppressive phenotype driven by the PTEN lipid phosphatase. In vivo, challenge with apoptotic cells triggers IDO-mediated induction of PTEN-expressing Tregs cells.

- In tumors, IDO induction by apoptotic cells may become relevant as the tumor attempts to inhibit immune responses to dying tumor cells following chemotherapy or immunotherapy. 


\section{Outstanding Questions}

- How do tumors recruit immune checkpoints such as IDO during their development? Is this a natural response to the inflammatory signals associated with malignant transformation, dying cells and DNA release? Or are there in addition, tumor-induced processes that exaggerate the amount of IDO induced by this inflammation? And, in a related question, what is the relative contribution of IDO expressed in immune cells and stromal cells versus that expressed by tumor cells?

- What is the role of IDO in enforcing tolerance to apoptotic tumor cells? Is IDO induced in the tumor microenvironment (or tumor-draining lymph nodes) by dying tumor cells after therapy? Does this elicit PTEN-expressing Treg cells, and thereby suppress the response to immunogenic tumor antigens? And, if so, can IDO-inhibitor drugs be used to promote epitopespreading and activation of new, endogenous $\mathrm{T}$ cells after chemotherapy or immunotherapy?

- What are the other relevant immunosuppressive mechanisms that must be blocked in order to maximize the effects of blocking IDO? Inhibiting IDO is not a magic bullet, and it seems to be a reproducible theme that IDOinhibitors work better in combination with CTLA-4 or PD 1 blockade, or with some form of chemotherapy or adoptive-transfer. But what are the mechanisms, and what is the most rational basis for combinations with other agents? 

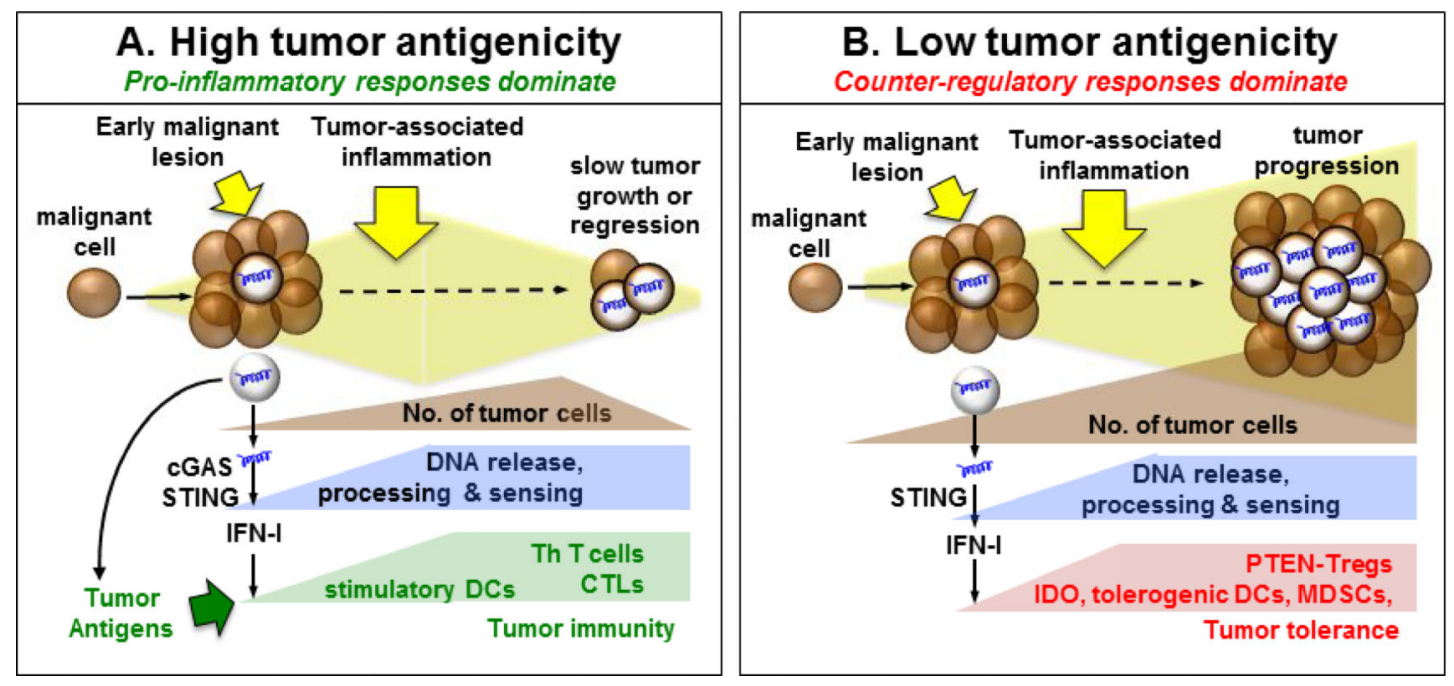

Figure 1. The Tipping Point: is DNA sensed to impede or incite tumorigenesis?

A. During tumor growth DNA from dying cells is sensed by cGAS to stimulate STING/ IFNa $\beta$ signaling, which potentiates immunogenic responses if tumors have relatively high antigenicity. These responses lead to tumor regression mediated by cytotoxic (CTL) and helper (Th) T cells. B. DNA is sensed to activate STING/IFNa $\beta$ signaling and induce IDO during tumorigenesis. IDO mediates dominant tolerogenic responses that activate Tregs to overcome immunogenic responses and promote tumorigenesis. These responses are more likely when tolerance thresholds are high due to low tumor antigenicity. 


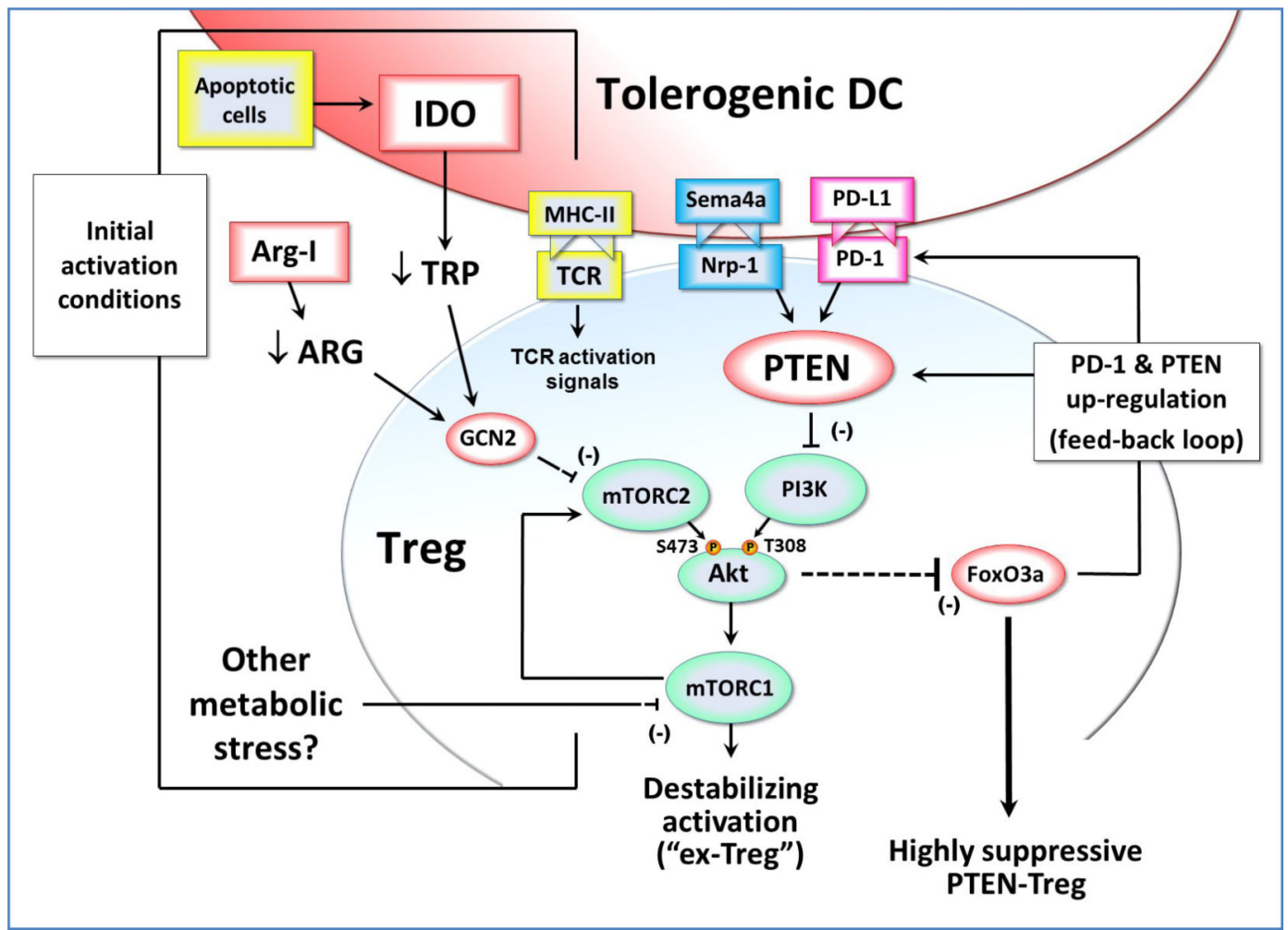

Figure 2. Effects of IDO exposure during Treg activation

During initial TCR-mediated activation of resting Tregs, signals via the Akt and mTOR pathways can potentially destabilize the Tregs and cause reprogramming into a proinflammatory helper-like phenotype ("ex-Tregs"). To prevent this, some signal must inhibit the mTOR/Akt axis during activation. If the antigen-presenting cell expresses IDO (e.g., due to up-regulation by apoptotic cells or other inflammatory signals) then this can inhibit mTORC2 signaling via a process mediated by low tryptophan and GCN2 kinase. In principle, depletion of other amino acids such as arginine (by local Arginase I) could create a similar GCN2-mediated inhibition of mTORC2. Potentially, other metabolic stresses in the tumor microenvironment might likewise affect mTORC1 and the feedback loop to mTORC2 and Akt. By whatever pathway, if Akt phosphorylation on the activating Ser473 residue is blocked, then the Treg is able to maintain expression of FoxO3a and acquire a highly suppressive phenotype that includes up-regulation of cell-surface PD-1 and the lipid phosphatase PTEN. PD-1 can signal via PTEN to inhibit PI3K activity, and thus block phosphorylation of the activating Thr308 residue on Akt. This self-sustaining feedback loop acts to stably maintain the inhibition of Akt long-term, even if the original IDO or other metabolic stress is removed. Neuropilin-1 (Nrp-1) can also activate PTEN, and thus may be able to establish a similar stable activation state in the Treg. 


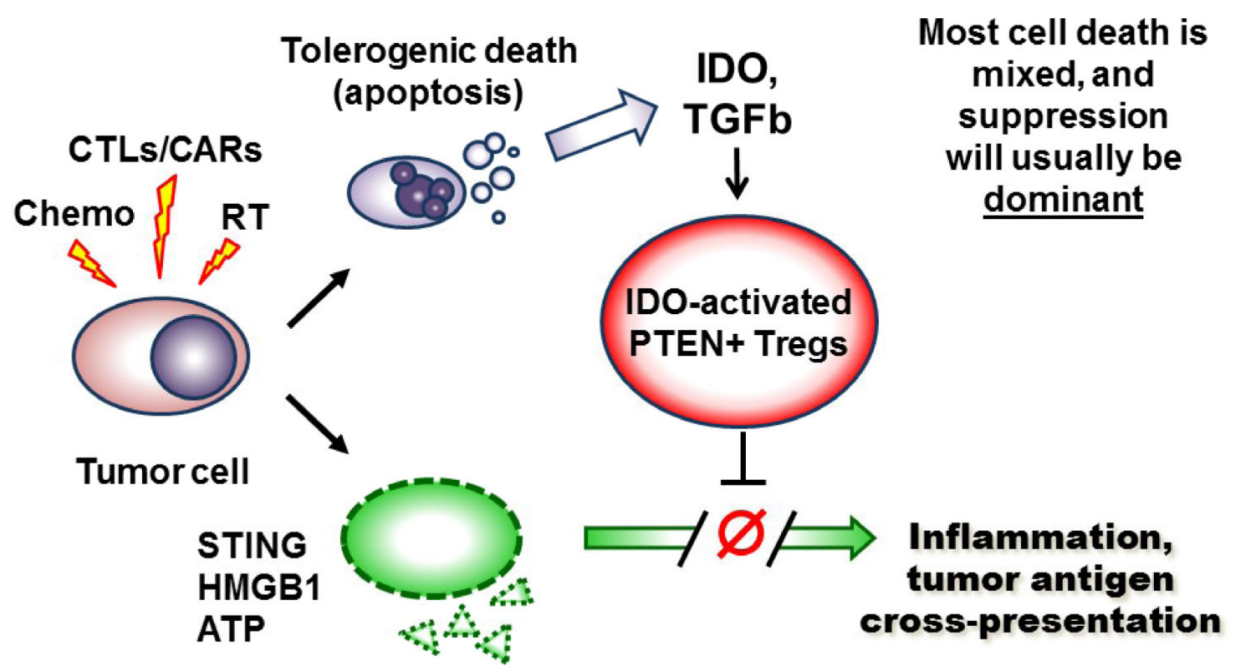

Immunogenic cell death

Figure 3. Potential model of tolerogenic versus immunogenic cell death in the tumor microenvironment

Tumor cells undergo a wave of cell death in response to chemotherapy, radiation or immunotherapy (e.g., T cell adoptive transfer, or other immunotherapy that activates cytotoxic T cells, CTLs). Some of the tumor cells may die via an immunogenic pathway that releases pro-inflammatory mediators such as HMGB1, ATP and STING. This immunogenic cell death has the potential to trigger inflammation, immunogenic cross-presentation of tumor antigens, and robust $\mathrm{T}$ cell activation. However, some fraction of the tumor cells also likely die by classical apoptosis, with consequent induction of immunosuppressive pathways such as TGF $\beta$, IDO and IDO-induced PTEN-Treg activation. Unless the pro-inflammatory signals are very strong, these immunosuppressive signals (particularly activation of the potent PTEN-Tregs) are likely to be dominant. Thus, the net outcome of tumor cell death is often immune suppression and tolerance. Underneath, however, the immunogenic cell death may still be present, and available to drive anti-tumor immune responses if the dominant suppression is blocked. 


\section{Table 1}

\section{Clinical trials of IDO-inhibitors}

\begin{tabular}{|l|l|l|l|}
\hline Strategy & Drug & Trial design & Trial number \\
\hline Combination with chemotherapy & indoximod & combination with taxane in breast cancer & NCT01792050 \\
\cline { 2 - 4 } & indoximod & $\begin{array}{l}\text { combination with temozolomide } \pm \text { radiation in refractory } \\
\text { glioblastoma brain tumors }\end{array}$ & NCT02052648 \\
\cline { 2 - 4 } & indoximod & $\begin{array}{l}\text { combination with temozolomide } \pm \text { radiation in pediatric brain } \\
\text { tumors }\end{array}$ & NCT02502708 \\
\cline { 2 - 4 } & indoximod & combination with gemcitabine + abraxane in pancreatic cancer & NCT02077881 \\
\cline { 2 - 4 } & epacadostat & combination with targeted Jak1 inhibitor or PI3K inhibitor & NCT02559492 \\
\hline \multirow{5}{*}{ Combination with checkpoint inhibitors } & epacadostat & combination with anti-CTLA-4 (ipilimumab) & NCT01604889 \\
\cline { 2 - 4 } & indoximod & combination with anti-CTLA-4 (ipilimumab) & NCT02073123 \\
\cline { 2 - 4 } & epacadostat & combination with anti-PD-1 (pembrolizumab) & NCT02178722 \\
\cline { 2 - 4 } & epacadostat & combination with anti-PD-L1 (atezolizumab) & NCT02298153 \\
\cline { 2 - 4 } & epacadostat & combination with anti-PD-L1 (MEDI4736) & NCT02318277 \\
\cline { 2 - 4 } & GDC-0919 & combination with anti-PD-L1 (atezolizumab) & NCT02471846 \\
\hline \multirow{5}{*}{ Combination with vaccines } & epacadostat & combination with NY-ESO-1 based vaccine in ovarian cancer & NCT02166905 \\
\cline { 2 - 4 } & indoximod & combination with Hyperacute vaccine + docetaxel in lung cancer & NCT02460367 \\
\cline { 2 - 4 } & epacadostat & combination with melanoma peptide vaccine & NCT01961115 \\
\cline { 2 - 4 } & epacadostat & $\begin{array}{l}\text { combination with Listeria-based mesothelin vaccine in ovarian } \\
\text { cancer }\end{array}$ & NCT02575807 \\
\hline
\end{tabular}

